\title{
Kolkata's brick sewer renewal: history, challenges and benefits
}

1 Nilangshu Bhusan Basu MEng

Principal Chief Engineer, Kolkata Municipal Corporation, Kolkata, India

2 Ayanangshu Dey PhD, CEng, MICE, MASCE, MIWA Senior Consultant, JB Enviro Consultants, Kolkata, India
3 Duke Ghosh PhD (Econ.), PGDBM

NWO postdoctoral fellow, Jadavpur University and fellow of The Ryoichi Sasakawa Young Leaders' Fellowship Fund, Kolkata, India
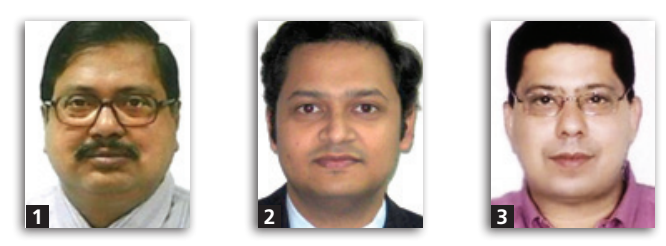

Many large-diameter brick sewers were built in central Calcutta (now Kolkata), India during the 1870s. However, over the past century they have deteriorated due to age, changed land-use patterns, lack of adequate maintenance and failure of limited past measures to upgrade them. In 2007, the Kolkata Municipal Corporation embarked on a major project of refurbishing the most critical stretches of these man-entry brick sewers with an estimated initial cost of $\mathbf{f 7 0}$ million. The first phase of this work is due for completion in 2014. A cost-benefit analysis shows an economic internal rate of return of over $15 \%$, amply justifying the investment towards sustainable renewal of an indispensable infrastructure component.

\section{Historical background}

The birth of Kolkata (formerly Calcutta) as a commercial centre was initiated by Job Charnock (1630-1692) of the English East India Company in 1690. It became a 'crowning glory' of British rule and served as the administrative capital of continental India from 1757 to 1911. Planning and development of sanitation and drainage infrastructure for Kolkata dates back to 1803 when governor-general Lord Wellesley (1797-1805) stressed the need for public drains and watercourses for a city receiving over $1600 \mathrm{~mm}$ annual rainfall, mostly spread over a defined monsoon period (June to September).

However, despite several important instructions issued by the governor-general, the work of providing a drainage system had been limited to construction of Beliaghata Canal (1810) and a survey of the town undertaken by John Schalch (1793-1825) (Smith, 1869). In 1821, Schalch suggested providing major brick masonry sewers from the River Hooghly to the proposed circular canal for conveying both sewage and storm water run-off ultimately to salt-water lakes in the eastern part of the city (present-day Salt Lake City). By 1835, several drainage proposals were formulated by a number of prominent individuals (Goode, 1916).

\subsection{The town scheme}

Finally, a scheme proposal by William Clark, MICE (1821-1880) was submitted to the municipal commissioners in November 1855 and forwarded to the local government for approval. In 1858, it was decided by the government that the scheme proposals be reviewed by Alexander
Rendel (1829-1918), who later became consulting engineer to the Indian government and president of the Institution of Civil Engineers in London. On reviewing Clark's exhaustive response to Rendel's proposals, the commissioners finally sanctioned Clark's scheme in 1859.

Clark's scheme - known as the 'town scheme' - was conceived to serve as a combined system along the natural slope of the terrain away from River Hooghly and towards the salt lakes, from west to east (Goode, 1916). Under the original scheme, five main sewers were initially planned to be laid along prominent roads with their branch sewers, associated works and outfalls (Figure 1).

Two main intercepting sewers were to be constructed: one along Upper Circular Road (now APC Roy Road) from Sova Bazaar Street to Dharrumtollah (Moulali) junction, where it was to be joined with another one along Lower Circular Road (now AJC Bose Road) coming from Zeerut Bridge near Tolly's Nallah to Moulali junction. Three other main sewers were planned from the River Hooghly to open into the APC Roy Road sewer along Nimtala Ghat Street, Kolutola Street and Dharrumtollah Street (now Lenin Sarani). A main outfall sewer (the 'Town Outfall') was to convey this combined flow to Palmer's Bridge pumping station.

The total catchment area of the scheme was $19 \cdot 1 \mathrm{~km}^{2}$ and anticipated sewage flow at the pumping station was $1 \cdot 27 \mathrm{~m}^{3} / \mathrm{s}$ from a contributing population of about 500000 . To induce self-cleansing velocity, arrangements were made to allow entry of tidal water into the sewers. The pumping station at Palmer's Bridge was deemed necessary to lift and convey the combined flow into a high-level sewer that would 
eventually dispose of it at Tangra Creek, $3 \cdot 2 \mathrm{~km}$ away. Its approval effectively dropped one of the modifications suggested by Rendel of joining the sewers by matching their soffits instead of inverts - this remains a serious defect in Kolkata's brick sewers (Goode, 1916).

Construction of the Lenin Sarani sewer was taken up first, along with its downstream works including the pumping station, to evaluate the philosophy of the proposals. This part of the system was commissioned in 1868. A special committee then reviewed the benefits of the initial works and decided to complete the whole town scheme as originally proposed. Its construction was completed in $1885-1886$, and by 1890 branches and laterals of around $177 \mathrm{~km}$ were added to the existing sanitation infrastructure.

\subsection{The suburban system}

Work on the 'suburban system' serving the southern part of the city was taken up in the late nineteenth century. Two main sewers constituted the suburban drainage system.

The first main sewer started from Kidderpore Docks, continued along Judges Court Road (in Alipore) after crossing Mominpur area, and crossed Tolly's Nallah by a siphon arrangement. Emerging on the eastern side, it continued along Hazra Road and culminated at Ballygange drainage pumping station. A second sewer was installed along Rashbehari Avenue that also terminated at Ballygange pumping station. This was followed by the supplementary 'Manicktala' and 'Tollygunge' systems. A number of canals in and around the city area also served as intermediate outfall points. The last system constructed in the city area was 'Tangra-Topsia' system.

\subsection{Current situation}

In total, there are now about $180 \mathrm{~km}$ of brick sewers in Kolkata. Of these, about $88 \mathrm{~km}$ are 'man-entry'sewers - that is sewers above $1.07 \mathrm{~m}$ (42 in.) diameter. Kolkata's wastewater and storm-water flow is pumped to dry-weather flow and storm-water flow channels respectively. These channels gravitate into Kulti River almost $36 \mathrm{~km}$ away from the city.

The underground sewer system was dimensioned for carrying storm water, which still constitutes the bulk of the combined flow. It was designed for a 2 month storm frequency. However, the sewers were designed for a much lower population concentration and significantly lower paved area than they are now subjected to.

Kolkata has experienced a major influx and growth of population over the past decades due to political events and evolving social and economic changes. The drainage scenario has also worsened due to loss of retention ponds, storm-water reservoirs and open areas being converted into paved surfaces to accommodate the additional population. The central area has thus started suffering from severe flooding.

\section{Rehabilitation project}

To formulate a workable and balanced refurbishment plan for the brick sewers, it was important to recognise and identify the problems with the existing sanitation system. Kolkata Municipal Corporation (KMC) had conducted several studies to assess the ground condition of its ailing sanitation infrastructure; the most important of these being the ones funded by the Asian Development Bank (1999-2000) and the World Bank (2000-2001).

These reports revealed the extremely dilapidated condition of the century-old brick sewers and the high level of siltation that could be

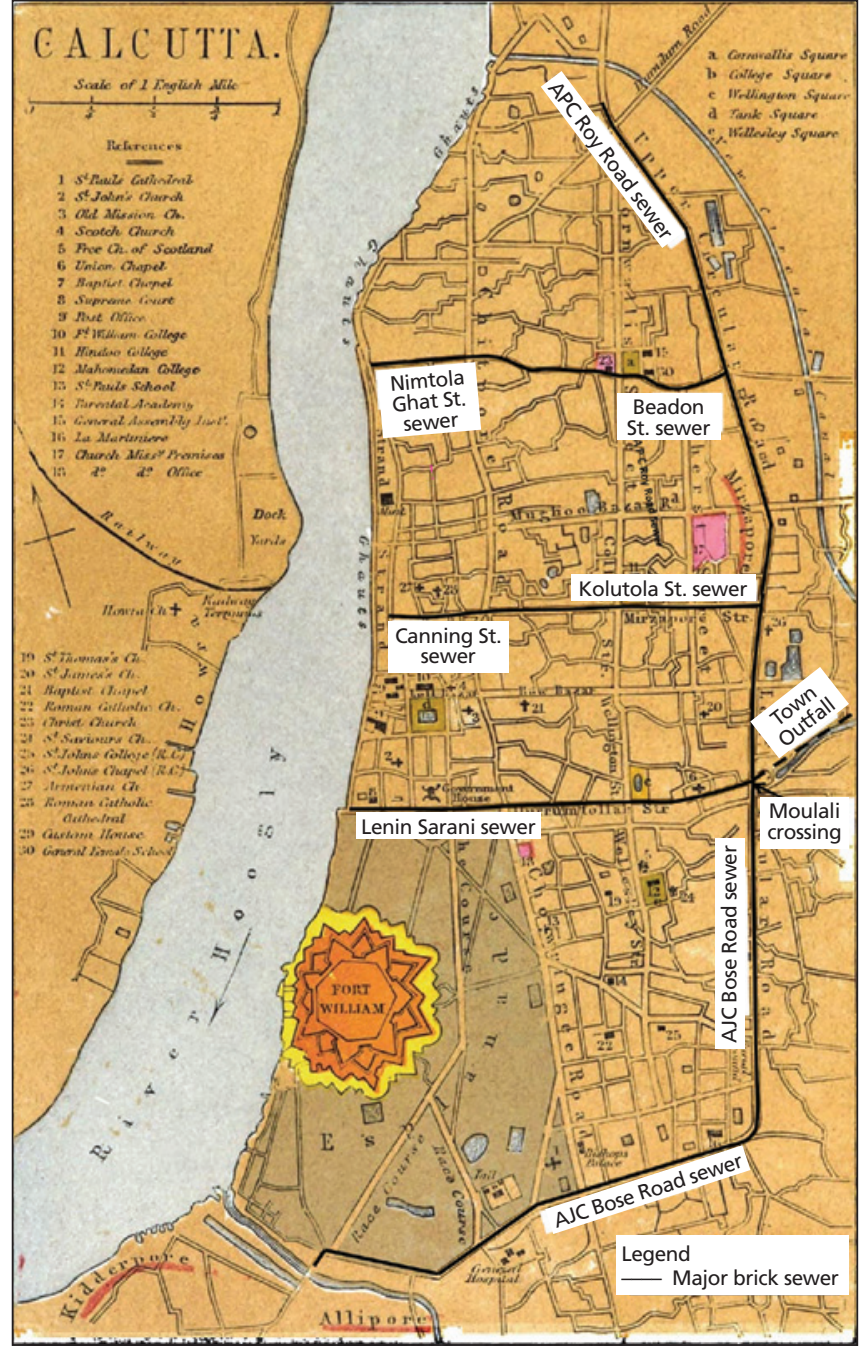

Figure 1. Layout of the five major brick sewers in Kolkata's central 'town system', which was completed to a British design in $1886-$ all have now been cleaned and relined. Town Outfall has yet to be rehabilitated. Map source: CMS (1862) 
Civil Engineering

Volume 166 Issue CE2 May 2013
Kolkata's brick sewer renewal: history, challenges and benefits Basu, Dey and Ghosh

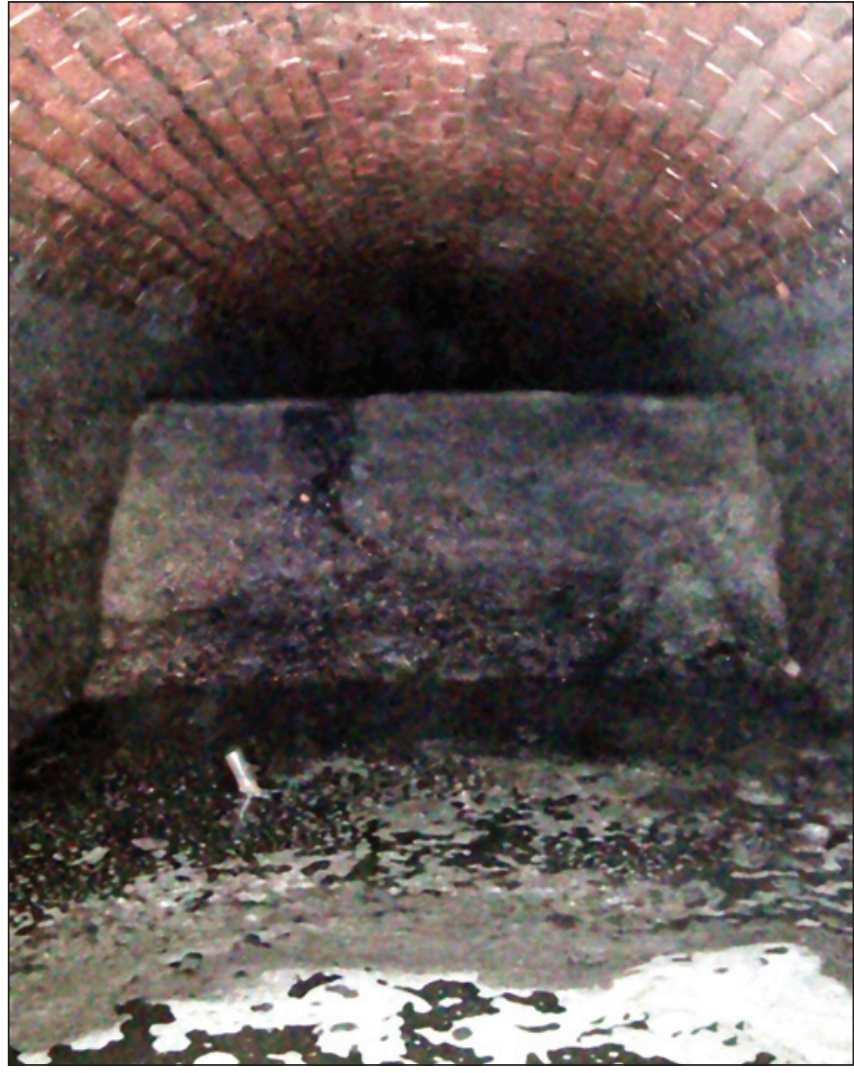

Figure 2. Over $50000 \mathrm{~m}^{3}$ of silt had to be removed from the $26 \mathrm{~km}$ of brick sewers - much of which had solidified into rock-like material



Figure 3. Utilities cutting across brick sewer soffits have caused many of the structural failures, with almost five collapses a week occuring in 2006

correlated to sewer collapses and frequent flooding, respectively. The corporation thus drew up an urgent rehabilitation plan in 2006, designed to restore the hydraulic capacity and structural integrity of the sewers.

The absence of screening for flow entering the sewers, indiscriminate dumping of solid waste, lack of public awareness and the very limited and localised sewer maintenance work were the main causes of siltation and deterioration. The amount of silt and debris deposited in sewers was found to be very high and to affect severely their serviceability (Figure 2).

Reports also indicated degeneration of bricks and eroded mortar, causing structural distress and failure in several places. Sewers had collapsed in various locations at different times on account open of increased traffic over the roads, too. Exposing brick sewers by open excavation for the purpose of laying other utility lines also caused structural failure of sewers (Figure 3). An indication of the level of siltation in individual sewers, together with a statistical record of collapses from 1980 to 2006, is given in Table 1. Collapses reached an alarming level of almost five per week in 2006.

\begin{tabular}{|c|c|c|c|c|c|c|c|c|c|c|}
\hline \multirow{2}{*}{$\begin{array}{l}\text { Name of } \\
\text { system }\end{array}$} & \multirow{2}{*}{$\begin{array}{l}\text { Basin } \\
\text { area: } \\
\text { km }^{2}\end{array}$} & \multirow{2}{*}{$\begin{array}{l}\text { Brick sewer } \\
\text { alignments } \\
\text { along road a }\end{array}$} & \multirow[t]{2}{*}{ Length: $m$} & \multicolumn{2}{|c|}{ Maximum dimension: $\mathrm{m}^{\mathrm{b}}$} & \multirow{2}{*}{$\begin{array}{c}\text { Total } \\
\text { collapses } \\
(1980-2006)\end{array}$} & \multirow{2}{*}{$\begin{array}{l}\text { Duration } \\
\text { of traffic } \\
\text { blockage: h } \\
(1980-2006)\end{array}$} & \multirow{2}{*}{$\begin{array}{l}\text { Reported } \\
\text { siltation: \% }\end{array}$} & \multirow{2}{*}{$\begin{array}{c}\text { Quantity } \\
\text { of silt } \\
\text { removed: } \\
\text { m }^{3}\end{array}$} & \multirow{2}{*}{$\begin{array}{l}\text { Terminal } \\
\text { pumping } \\
\text { station }\end{array}$} \\
\hline & & & & Vert. & Hor. & & & & & \\
\hline \multirow[t]{7}{*}{ Town } & \multirow[t]{7}{*}{$19 \cdot 1$} & AJC Bose Road & 4986 & $2 \cdot 78$ & $2 \cdot 13$ & 619 & 3433 & $50-70$ & 12069 & \multirow{7}{*}{$\begin{array}{l}\text { Palmer } \\
\text { Bridge }\end{array}$} \\
\hline & & APC Roy Road & 4631 & $2 \cdot 79$ & $2 \cdot 15$ & 627 & 3769 & $70-85$ & 12288 & \\
\hline & & $\begin{array}{l}\text { Nimtola Ghat } \\
\text { Street }\end{array}$ & 1785 & $2 \cdot 39$ & $1 \cdot 86$ & 215 & 1678 & $70-75$ & 4165 & \\
\hline & & Beadon Street & 747 & $2 \cdot 42$ & 1.89 & 114 & 787 & 70 & 1801 & \\
\hline & & Canning Street & 557 & $2 \cdot 42$ & $1 \cdot 89$ & 133 & 777 & 30 & 522 & \\
\hline & & Kolutola Street & 2000 & $2 \cdot 42$ & 1.89 & 258 & 1743 & 85 & 5749 & \\
\hline & & Lenin Sarani & 2787 & $2 \cdot 39$ & 1.88 & 333 & 1931 & $70-75$ & 6668 & \\
\hline \multirow[t]{2}{*}{ Suburban } & \multirow[t]{2}{*}{$25 \cdot 7$} & $\begin{array}{l}\text { Hazra Road } \\
\text { (circular) }\end{array}$ & 4044 & \multicolumn{2}{|c|}{ Diameter $1 \cdot 64-2 \cdot 17$} & 457 & 3249 & $75-80$ & $8892^{c}$ & \multirow[t]{2}{*}{ Ballygange } \\
\hline & & $\begin{array}{l}\text { Rashbehari Avenue } \\
\text { (horseshoe) }\end{array}$ & 4813 & 3.05 & $2 \cdot 13$ & 571 & 4242 & 70 & $362^{c}$ & \\
\hline \multicolumn{3}{|l|}{ Total } & 26350 & & & 3327 & 21609 & & 52516 & \\
\hline \multicolumn{11}{|c|}{$\begin{array}{l}\text { a Sewers are named after their alignment along these prominent roads. Sewers are oval-shaped unless indicated. } \\
\text { b Maximum clear vertical and horizontal dimensions of sewers are indicated and it varies along sewer length. } \\
\text { c Work is ongoing in these sewers. }\end{array}$} \\
\hline
\end{tabular}


The $£ 70$ million renewal project for the most critical $26 \mathrm{~km}$ of brick sewers (priority phase 1) was approved in 2006-2007 for contributory funding under the Jawaharlal Nehru national urban renewal mission, a government initiative to develop and refurbish India's urban infrastructure. The cost was met by $35 \%$ federal funding through the mission, $35 \%$ funding from the government of West Bengal and 30\% from KMC and other sources.

Global tenders were invited by the corporation in 2007 to award the works to contractors having adequate and proven track records to carry out a sewer rehabilitation programme of this magnitude and complexity. Work started on site in 2008 and is due for completion in 2014. The project was designed and is being supervised by KMC's planning and development department in conjunction with its sewer rehabilitation consultant.

\section{Trenchless technology}

A primary criterion for the project was to cause as little disruption to normal urban life as possible. Other issues considered were the extent of the programme, the sizes of the sewers involved, probable logistical challenges and suitable rehabilitation methods meeting the objectives. A decision to select a trenchless method was taken after careful review of available data and prevailing field conditions in the target area.

Trenchless technology was probably the only way by which a project of this magnitude could be undertaken and executed in such a heavily congested urban setting. Traditionally, brick sewer repairs were undertaken in open excavation for identification and accessibility. This involved shutting down roadways, diversion of traffic and stoppage or diversion of other utility services during repair. In such cases, the social costs could be many times the direct repair cost. The top half of the brick arch was usually dismantled, after which new brick walls were built on both sides and a reinforced concrete slab cast on top, with formwork removed by way of the manhole shafts. The original sewer profile was not restored.

Brick sewer rehabilitation has been done successfully using castin-place pipe lining in Newark (Pennington et al., 2008). However, for Kolkata, inserting prefabricated glass-reinforced plastic (GRP) liners inside the existing sewers was judged to be the most suitable method. Major factors that dictated the selection were the suitability of application under prevailing field conditions, life expectancy of the product, track record, anticipated capital and operation and maintenance cost, available funds, product and skill availability, and size of sewer. Also, several other municipal corporations in India (Mumbai and Delhi in particular) have already resorted to using GRP liners for brick sewer repairs as an overall low-cost alternative to other methods of renewal (Downey, 2006).

The GRP liners selected for the project are type II 'stand-alone' liners as per the Water Research Centre manual (WRC, 2004). The liners are designed to withstand all overburden and hydraulic loadings with an expected life of over 50 years.

They are of the socket and spigot type, and are field-jointed with a rubber gasket after placement. The thickness of the liners was selected based on anticipated loading and they were tested in the laboratory for flotation, external pressure grouting, hydrostatic, and ground and traffic loadings.

The flexural modules for short-term and long-term durability are $11000 \mathrm{MPa}$ and $5500 \mathrm{MPa}$, respectively. They are designed to comply with deflection, strength and buckling requirements as stipulated by the relevant standards (ASTM, 2011; SA, 1989; WRC, 1986).

The smoother surface of the liners will offer less frictional resistance to flowing water and no reduction in the original hydraulic capacity of sewers is expected. However, the annular space between the liner and host sewer is a probable place for accumulation of gases (under anaerobic conditions) that could potentially have serious consequences during operation. The space is thus grouted with concrete of stipulated specification after installation of liners, which also improves its structural integrity (Figure 4).

\section{Trenchless technology was probably the only way by which a project of this magnitude could be undertaken and executed in such a heavily congested urban setting}

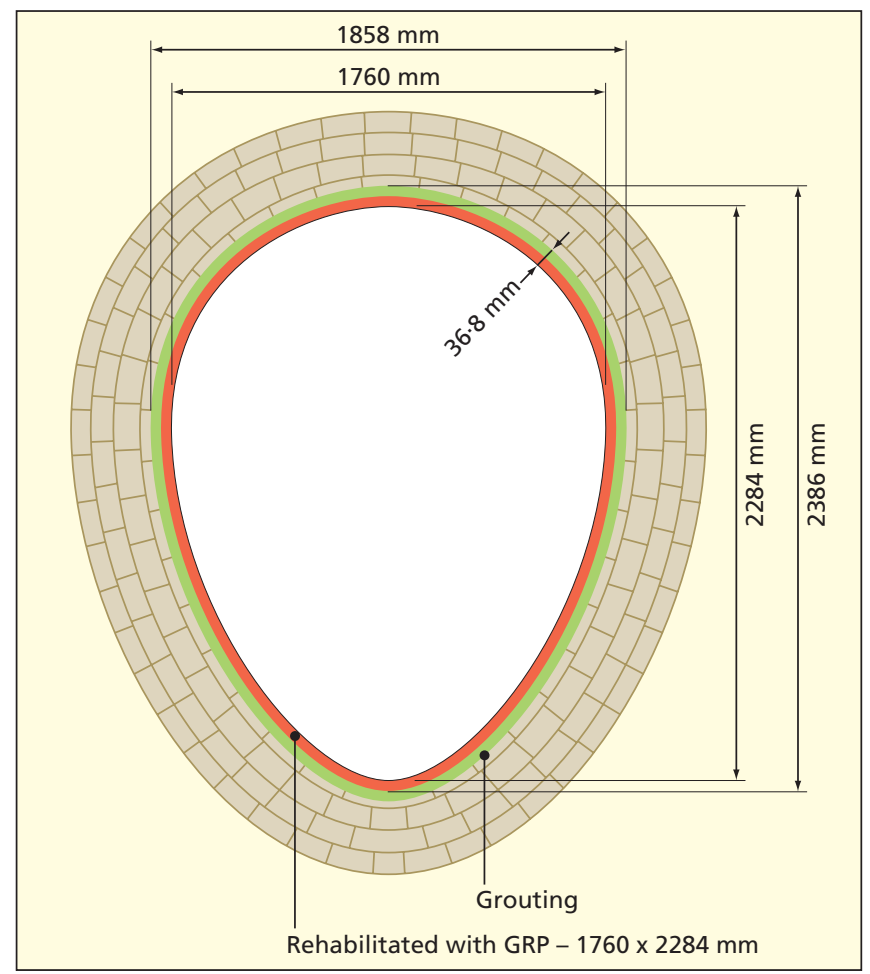

Figure 4. Typical cross-section of a glass-reinforced plastic liner inside an egg-shaped brick sewer - the space between the liner and sewer is grouted to avoid a dangerous build-up of gas (GRP, glass-reinforced plastic) 


\section{Due to tidal effects in the River Hooghly, to which most of the sewers were connected, submersible pumps of high discharge capacity and high delivery head were used to divert the flow}

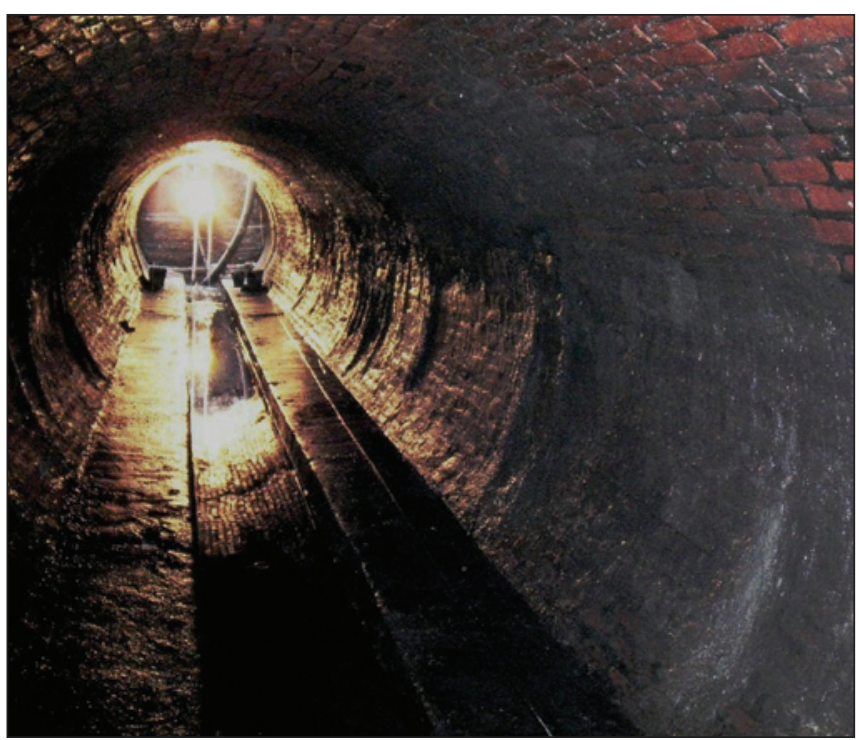

Figure 5. A horseshoe-shaped brick sewer ready for lining after careful de-silting

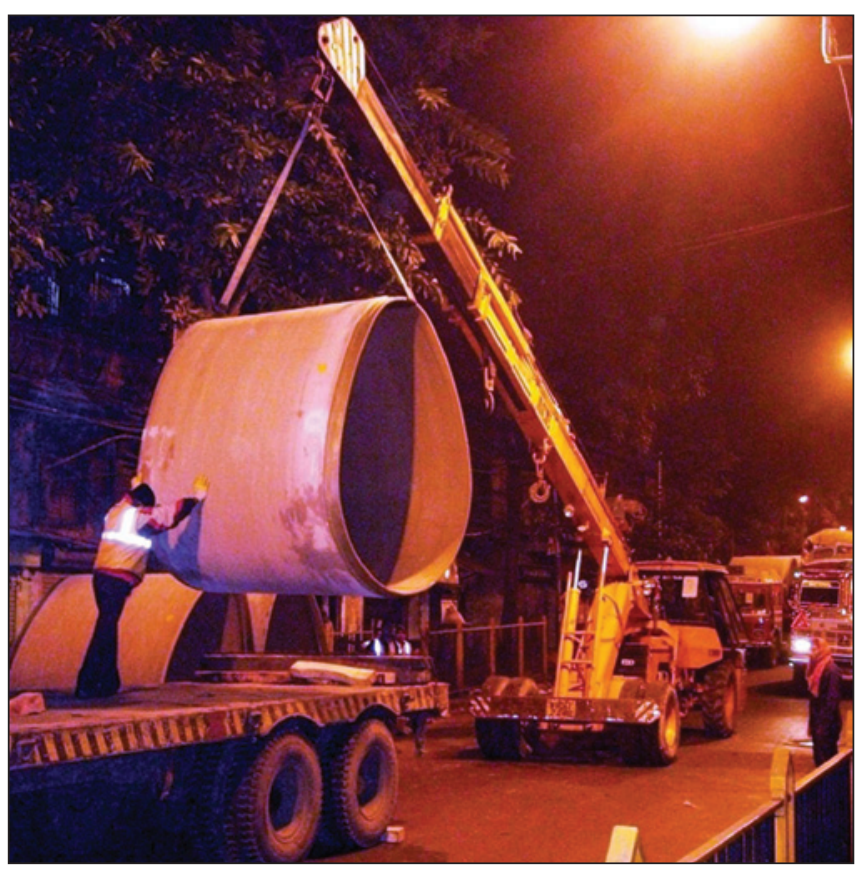

Figure 6. Liner sections being delivered at night, when most work was carried out due to reduced sewage flows

\section{Logistical challenges}

After work started in 2008, significant challenges were faced both by the contractors and $\mathrm{KMC}$ while working in what is one of the most congested urban areas in the world. Such challenges involved logistical, technical and administrative issues and had to be resolved quickly to maintain the project schedule.

In particular, there was very little reliable information about extensions to the main network that had been carried out over the last 100 years. A detailed closed-circuit television survey of the whole sewerage network was thus carried out after de-silting to record hydraulic properties, interconnections, status and the presence of other utilities, such as water mains, high-voltage electricity cables and communications cables. Before insertion of liner material inside the sewers could be started, all utility lines had to be isolated and then relocated in close coordination with the relevant departments.

Usually, flow diversion for major sewers is arranged by selecting an alternative sewer as a 'bypass'. However, in this case, no such sewers were available, so high-density polyethylene bypass pipes were temporarily laid along existing main roads parallel to the sewers. These were laid allowing passage for cross roads on either side of the main road.

Also, flow diversion is normally done by deploying self-priming pumps at the ground level, but in Kolkata the level of water in the sewers could not be controlled with such pumps due to tidal effects in the River Hooghly, to which most of the sewers were connected. As a result, submersible pumps of high discharge capacity and high delivery head were used to divert the flow. These pumps were found to be small enough to be accommodated inside the sewers and were sufficiently effective to drain the flow in a reasonable amount of time.

Flow diversion in the trunk sewers is generally done using pneumatic balloons for short periods and semi-permanent brick or stone walls for extended periods. However, balloons of sufficient size were not available locally, so shaped and stiffened steel plates were used as 'stanks' initially. Subsequently, much heavier reinforcedconcrete-filled sections of GRP liner were used, measuring $0.3 \mathrm{~m}$ wide. It was possible to remove both types of stank quickly in the event of sudden and intense rainfall by using powered winches.

Removing silt from sewers posed quite a challenge as this was probably the first time such sewers were being de-silted since their commissioning more than a century ago. At many places, the silt was found to have formed rock-like deposits, which could not be removed by simple manual excavation (Figure 2). Chisels, jack hammers, ground breakers and even fork lifts at a few places were employed to dislodge solidified silt, although great care had to be taken not to damage the sewer structure (Figure 5).

De-silting produced a huge quantity of excavated material for disposal. The silt contained granular material along with clayey organic deposits, inert materials and traces of heavy metals. The estimated quantity of silt removed was over $50000 \mathrm{~m}^{3}$, and it was disposed of in secured sanitary landfills in an environmentally acceptable manner.

Most of the rehabilitation work was undertaken during night hours (usually between 2300 and 0500), when wastewater flow inside the sewers was minimal (Figure 6). The only visible evidence of work on the surface was some barricading at certain places around access shafts and manholes, which caused some localised and limited restriction to traffic and pedestrian movement. 
The liners had to be manoeuvred within very narrow streets in the city area and were lowered individually through access manholes for carrying them further inside the sewers for proper placement (Figure 7)

Connections to the major sewers are generally only at manhole locations, but several unauthorised connections were found between manholes. These were blocked with pneumatic plugs during lining work and then reopened.

\section{Safety, sustainability and economics}

Safety is a primary concern for sewer rehabilitation work, especially for people working within the sewers (Figure 8). The use of personal protective equipment was mandatory, including clothing, helmet, gloves, boots, belt, anchoring rope and face-mask, and a logbook was maintained for all workers entering the sewers. The complexity of the work and associated hazards were adequately explained to the workers by the supervising authorities.

All precautionary measures were adopted and strict adherence to these norms has resulted in no fatalities in 4 years. Carrying out most of the installation works during night hours significantly helped to avoid possible hazards associated with working during normal hours in such extremely congested urban areas. The working areas in congested roads and around access manholes were clearly demarcated, guarded and isolated during daytime for traffic diversion

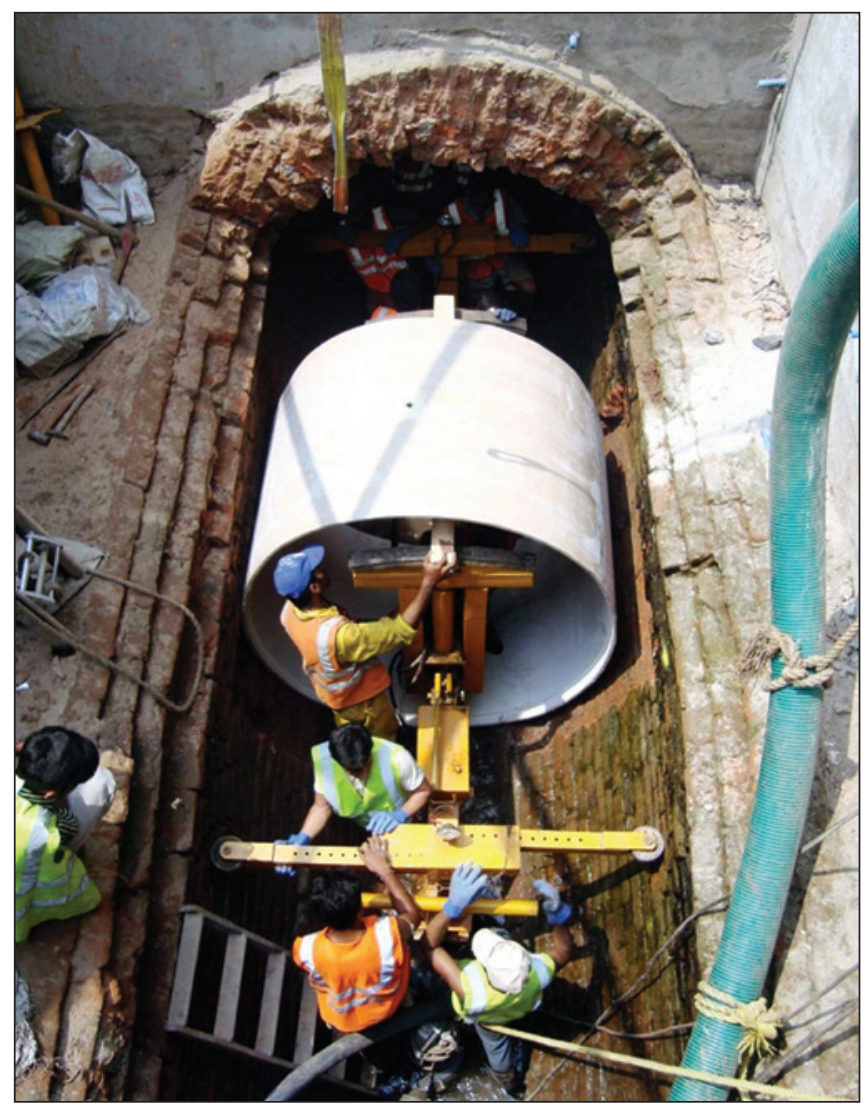

Figure 7. Liner section being placed inside a sewer by way of an access manhole and pedestrian movement.

With regard to sustainability, in addition to providing a significantly improved sewerage system with minimal social and environmental impact, the liners were manufactured locally - creating further employment and reducing material transport costs.

A cost-benefit analysis provides economic justification for the investment using a framework prescribed by the Asian Development Bank (ADB, 1997). Following data published by the Reserve Bank of India (Mohanty, 2011), the annual rate of inflation considered was $7 \cdot 55 \%$, and benefits from the project were deemed to accrue over a period of 39 years (2012-2050). Given that the renewal life of the rehabilitated components is estimated to be 70 years, the analysis covered approximately $55 \%$ of the life span of the project. This in turn resulted in a conservative approach, as extending this period would increase the benefit-to-cost ratio and make project more economically viable.

The most important benefits expected to accrue from the project are the health-related benefits and savings in income loss due to a reduction in flooding. Savings in health costs are mostly due to avoidance of expenditure incurred for waterborne diseases. Earlier studies (Roy et al., 2008) had indicated monthly expenditure incurred by households in the city on treatment of waterborne diseases. The weighted average of the monthly expenditure is $£ 5.35$ per household at 2011 prices. Problems in accessing workplaces and carrying out usual business are some of the factors contributing to income loss. On the



Figure 8. All personnel working in the sewers were required to follow strict safety procedures 


\section{Civil Engineering}

Volume 166 Issue CE2 May 2013
Kolkata's brick sewer renewal:

history, challenges and benefits

Basu, Dey and Ghosh

\begin{tabular}{|c|c|c|c|c|c|c|}
\hline \multirow[t]{2}{*}{ Brick sewer } & \multicolumn{2}{|c|}{ Project schedule } & \multicolumn{2}{|c|}{ Contract cost } & \multirow{2}{*}{$\begin{array}{l}\text { Rehabilitation } \\
\text { cost: } \\
\text { fmillion } / \mathrm{km}\end{array}$} & \multirow[t]{2}{*}{ Contractor } \\
\hline & Start & Finish & INR million & $f$ million a & & \\
\hline AJC Bose Road & October 2008 & November 2011 & 930 & $12 \cdot 83$ & $2 \cdot 57$ & \multirow{2}{*}{$\begin{array}{l}\text { Angerlehner Hoch- und Tiefbau } \\
\text { Gesellschaft mbH, Pucking, Austria }\end{array}$} \\
\hline APC Roy Road & November 2007 & September 2010 & 795 & $10 \cdot 97$ & $2 \cdot 37$ & \\
\hline Nimtola Ghat Street & November 2008 & January 2011 & 383 & $5 \cdot 28$ & $2 \cdot 96$ & \multirow{2}{*}{$\begin{array}{l}\text { Michel Bau GmbH \& Co. KG, } \\
\text { Neumünster, Germany }\end{array}$} \\
\hline Beadon Street & November 2011 & May 2012 & 158 & $2 \cdot 19$ & 2.93 & \\
\hline Canning Street & November 2011 & May 2012 & 104 & $1 \cdot 44$ & $2 \cdot 59$ & \multirow{2}{*}{$\begin{array}{l}\text { Angerlehner Hoch- und Tiefbau } \\
\text { Gesellschaft mbH, Pucking, Austria }\end{array}$} \\
\hline Kolutola Street & November 2007 & January 2011 & 368 & $5 \cdot 08$ & $2 \cdot 54$ & \\
\hline Lenin Sarani & April 2008 & May 2010 & 603 & $8 \cdot 50$ & $2 \cdot 99$ & \multirow{2}{*}{$\begin{array}{l}\text { Michel Bau GmbH \& Co. KG, } \\
\text { Neumünster, Germany }\end{array}$} \\
\hline Hazra Road & November 2011 & May 2014 & 720 & 9.93 & $2 \cdot 46$ & \\
\hline Rashbehari Avenue & November 2011 & September 2013 & 1018 & 14.05 & $2 \cdot 92$ & $\begin{array}{l}\text { Angerlehner Hoch- und Tiefbau } \\
\text { Gesellschaft mbH, Pucking, Austria }\end{array}$ \\
\hline Total & & & 5079 & $70 \cdot 27$ & & \\
\hline
\end{tabular}

${ }^{a}$ Adjusted for rate of inflation as indicated in the text and adopting midmarket rate in the middle of the calendar year 2011 for conversion of INR into $\mathrm{f}$

Table 2. Project cost and current status (Basu and Dey, 2012)

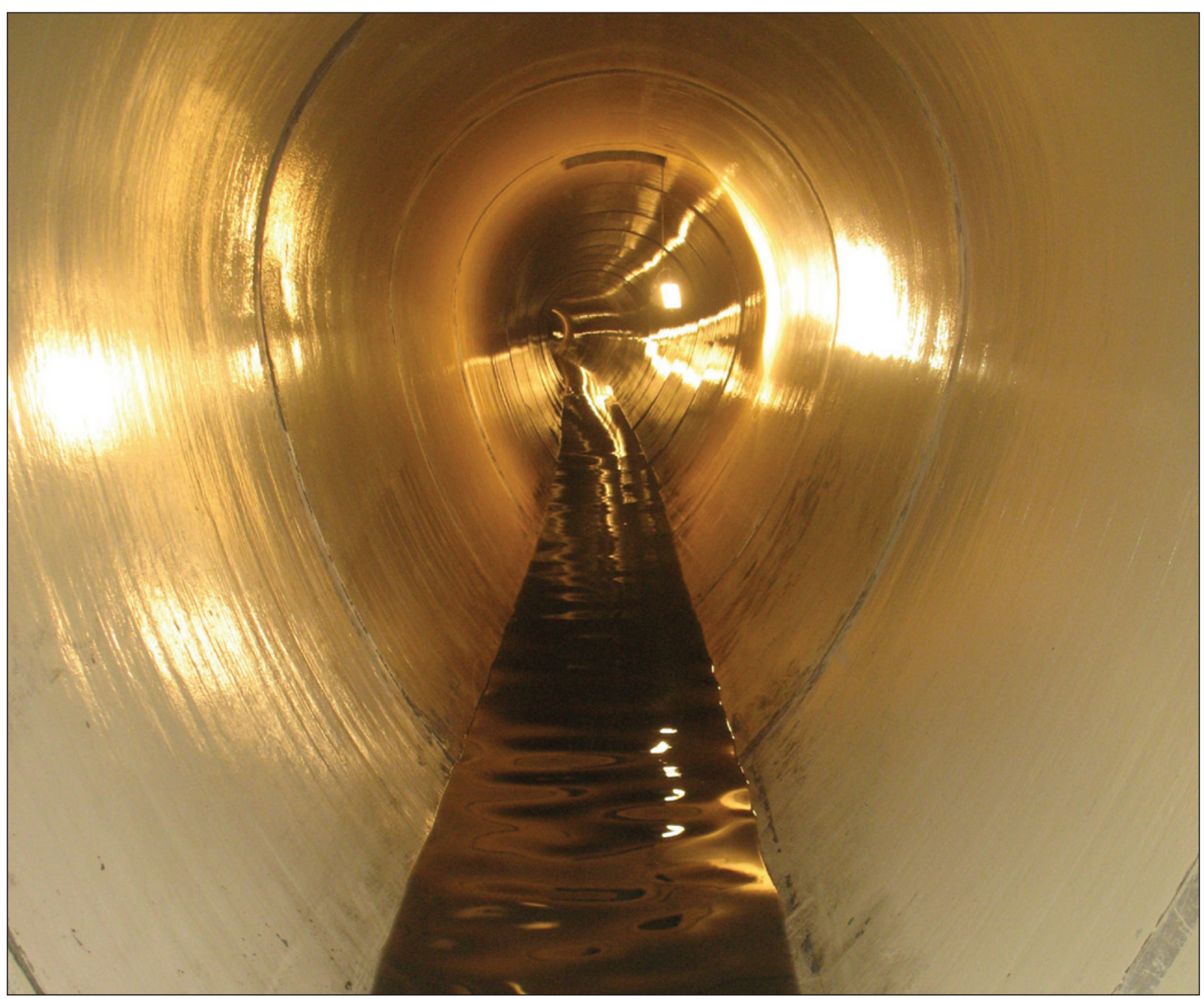

Figure 9. View inside a smooth-lined, egg-shaped brick sewer - local residents and workers are immediately benefitting from improved sanitation and reduced flooding 
other hand, cleaning of houses, establishments, cars and commuting in flooded areas are sources of additional expenditure. The average daily income of the households is assumed to be $£ 6.63$ at 2011 prices.

The cost-benefit analysis was carried out by using a discounted cash flow technique to obtain the economic internal rate of return and economic net present value for the investment. The economic internal rate of return was compared with the economic opportunity cost of capital. Given the complexity of estimating country-specific economic opportunity cost of capital, as followed in the case of the projects financed by the Asian Development Bank, an annual discount rate of $12 \%$ had been used as a proxy. This approach has gained recognition in the literature analysing the economic and social costs and calculating the benefits of infrastructure projects (Inocencio et al., 2007; Murty et al., 2006).

The calculated economic internal rate of return of the project was $15.35 \%$, which is well above the $12 \%$ economic opportunity cost of capital, which is usually used as a criterion for assessment. The economic net present value was estimated as $£ 18.35$ million. Since economic net present value is greater than zero and economic internal rate of return is over $12 \%$, the investment incurred is justified and economically viable as the economic benefits exceed the economic costs.

It is also important to note that certain benefits - reduced burden of vector-borne diseases such as malaria and dengue, improved environmental conditions, visual appeal of the city, reduction in traffic congestion, and reduction in emission of pollutants such as sulfur dioxide, nitrous oxides, carbon dioxide, particulate matters and black carbon - have not been considered in the cost-benefit analysis. Inclusion of such benefits and stretching the period of analysis covering the entire life of the project will further improve the economic internal rate of return and economic net present value.

\section{Current status}

The cost and current status of the various brick sewer rehabilitation works in Kolkata are given in Table 2.

Works for the sewers in the town system have been completed and the refurbished sewers have been re-commissioned (Figure 9). Works on two remaining main sewers in the suburban system are ongoing and scheduled for completion by 2014 .

Significant benefits in terms of better sanitation and reduced flooding are already being experienced in the areas around the completed sewers.

The project team is now adequately experienced to continue with future rehabilitation programmes on Kolkata's brick sewers.

\section{Acknowledgements}

The authors would like to thank Vernon Downes, in particular, and Michel Head of WERM Wink JV India Pvt. Ltd for their contribution to the project. Support received from the then mayor and commissioner of Kolkata Corporation for initiating the project is also gratefully acknowledged.

The Kolkata Municipal Corporation project team comprised chief engineer Subrata Kumar Seal, deputy chief engineers Somnath Boral, Biplab Paul, Pranab Kumar Das, executive engineers Sushil Kumar Mondal, Sarbani Kundu, Sudipto Chattopadhyay and Samiran Ghosh, and other support staff.

The project contractors were Angerlehner Hoch- und Tiefbau Gesellschaft mbH, Pucking, Austria and Michel Bau GmbH \& Co. KG, Neumünster, Germany.

\section{References}

ADB (Asian Development Bank) (1997) Guidelines for the Economic Analysis of Projects. Economics and Development Resource Centre, Manila, Philippines. ASTM (2011) D3262: Standard specification for 'fiberglass' (glass-fiber-reinforced thermosetting-resin) sewer pipe. ASTM International, West Conshohocken, PA, USA. Basu NB and Dey A (2012) New life for Kolkata's sewers. Civil Engineering, ASCE 82(7/8): 68-75.

CMS (Church Missionary Society) (1862) The Church Missionary Atlas, 3rd edn. Shelley, Jackson and Halliday, London, UK. See

http://wiki.fibis.org/index.php?title=File:Calcutta_map_1862_.jpg (accessed 06/02/2013).

Downey D (2006) Trenchless technology: a modern solution for clean-flowing cities. Proceedings of the Institution of Civil Engineers - Civil Engineering 159(5): 26-30, http:// dx.doi.org/10.1680/cien.2006.159.5.16.

Goode SW (1916) Municipal Calcutta: its Institutions in their Growth and Origin. T \& A Constable, Edinburgh, UK, reprinted in 2005 by Kolkata Municipal Corporation and MacMillan, New Delhi, India.

Inocencio A, Kikuchi M, Tonosaki M et al. (2007) Costs and Performance of Irrigation Projects: a Comparison of Sub-Saharan Africa and Other Developing Regions. International Water Management Institute, Colombo, Sri Lanka, IWMI Research Report 109.

Mohanty D (2011) Changing Inflation Dynamics in India. Reserve Bank of India, Mumbai, India, speech delivered at the Motilal Nehru National Institute of Technology (MNNIT), Allahabad, India. See http://www.rbi.org.in/scripts/BS_SpeechesView.aspx?id=591 (accessed 06/02/2013).

Murty MN, Dhavala KK, Ghosh M and Singh R (2006) Social Cost-Benefit Analysis of Delhi Metro. Institute of Economic Growth, Delhi University Enclave, Delhi, India, Working Paper 273. See http://iegindia.org/workpap/wp273.pdf (accessed 06/02/2013).

Pennington RA, Gersley KA, Gagliostro A et al. (2008) Serving a city's sewers. Civil Engineering, ASCE 78(12): 60-67.

Roy J, Kanjilal M, Maitra S, Ghosh M and Dutta S (2008) Study on Willingness to Pay and Other Related Issues to Water Service Charge. Global Change Programme, Jadavpur University, Kolkata, India, final report submitted to KMC/KEIP.

SA (Standards Australia) (1989) AS 3571: Glass filament reinforced thermosetting plastics (GRP) pipes - polyester based - water supply, sewerage and drainage applications. Standards Australia Limited, Sydney, NSW, Australia.

Smith DB (1869) Report on the Drainage and Conservancy of Calcutta. Bengal Secretariat press, Calcutta, India.

WRC (Water Research Centre) (1986) Specification for Glassfibre Reinforced Plastics (GRP) Sewer Linings. WRC, Swindon, UK, information and guidance note 4-34-02. WRC (2004) Sewer Rehabilitation Manual, 4th edn. Water Research Centre, Swindon, UK. 